\title{
SARCÓIDE EQUINO - RELATO DE CASO
}

\section{NICHELE ${ }^{1}$; C.B. VIANNA ${ }^{2}$; S. RODASKI ${ }^{1}$; A.F.P.F. WOUK ${ }^{1}$; I. SUSKO ${ }^{1}$; I. ZULIAN ${ }^{1}$;}

S.D. GUÉRIOS ${ }^{2}$; M.A. PERRONI ${ }^{3}$

${ }^{1}$ Departamento de Medicina veterinária, Setor de Ciências Agrárias, Universidade Federal do Paraná; ${ }^{2}$ Mestrandas do Curso de Pós-Graduação em Ciências Veterinárias, Universidade Federal do Paraná; ${ }^{3}$ Aluna do Curso de Medicina Veterinária, Universidade Federal do Paraná.

O sarcóide é uma neoplasia cutânea,

fibroblástica, não metastática e localmente invasiva dos equídeos. As lesões neoplásicas podem ocorrer isoladas ou em grupos, sendo a região cervical, cabeça (periocular, pinas e comissura labial) e membros os locais de maior incidência. Os sarcóides eqüino podem se apresentar de diferentes formas macroscópicas e suas lesões tem sido classificadas em três tipos principais: verrucosa, fibroblástica e mista. Na forma verrucosa as lesões apresentam superfície seca, plana e córnea, podendo ser sésseis ou pedunculadas. O tipo fibroblástico apresenta lesões com aspectos variados, algumas como nódulos fibrosos bem circunscritos e recobertos com epiderme intacta e outras se apresentam em grandes massas ulceradas, muitas vezes recobertas por tecido necrótico. O tipo misto é menos freqüente e é classificado como uma forma tumoral de transição. Um sarcóide verrucoso pode se transformar em fibroblástico em resposta a traumatismos ou a uma biópsia cirúrgica. A idade média de aparecimento desses tumores é de 7 anos. Um eqüino da raça Andaluza, do sexo masculino e com 12 anos de idade foi encaminhado ao Hospital Veterinário da Universidade Federal do Paraná, devido ao aparecimento de nódulos na região ventral do abdome e região inguinal. Para estabelecer um diagnóstico específico realizou-se uma biópsia incisional e a amostra foi encaminhada para exame histopatológico. Os cortes histológicos apresentaram áreas densamente celularizadas compostas por células fusiformes, irregularmente dispostas e áreas menos densas onde predominaram células neoplásicas com aspecto estrelado, característico de sarcóide. O paciente foi submetido à anestesia geral inalatória e realizada a excisão cirúrgica das massas tumorais, com margem de segurança de $3 \mathrm{~cm}$. Devido ao alto índice de recidiva, aproximadamente $50 \%$, é indicado o uso de outras técnicas terapêuticas, como a imuno, rádio e quimioterapia, combinadas à excisão cirúrgica. O tratamento cirúrgico pode ser realizado com sucesso se o tecido neoplásico for bem delimitado e haja quantidade suficiente de tecido sadio para debridação, fechamento primário e cicatrização por primeira intenção. 